\title{
Risk Management Impact on Non-Performing Loans and Profitability in the Namibian Banking Sector
}

\author{
Bernardus Franco Maseke, Eswual M. Swartz \\ Faculty of Economics and Management Science, University of Namibia, Keetmanshoop, Namibia \\ Email: fmaseke@gmail.com, eswualswartz@gmail.com
}

How to cite this paper: Maseke, B.F. and Swartz, E.M. (2021) Risk Management Impact on Non-Performing Loans and Profitability in the Namibian Banking Sector. Open Access Library Journal, 8: e6943.

https://doi.org/10.4236/oalib.1106943

Received: October 28, 2020

Accepted: June 7, 2021

Published: June 10, 2021

Copyright () 2021 by author(s) and Open Access Library Inc.

This work is licensed under the Creative Commons Attribution International License (CC BY 4.0).

http://creativecommons.org/licenses/by/4.0/

\section{(c) (i) Open Access}

\begin{abstract}
The Banking sector has a pivotal role in the development of an economy. It is the key driver of economic growth of the country. Various literature revealed that non-performing loans were one of the causes of the financial crisis in 2007. The rise in non-performing loans has been taken under consideration by many banks in the world, as banks look at different methods on how to reduce non-performing loans. The following study was carried out with the objective to analyze the impact of risk management on non-performing loans in the country and identifying different strategies used around the world that assists banks in battling non-performing loans. The study used the four major commercial banks in Namibia as samples. The study analyzed two theories Agency Theory and Credit default theory. The study used only secondary data to answer the research objectives. The limitations of the study were that the study only looked at non-performing loans of credit risks the banks face. The study was not able to use all the commercial banks as samples to gather data. The strategy of the study was an archival strategy and the study used a qualitative approach. The study found that the Namibian banks experienced an increase throughout the five years in both profits and non-performing loans. The year 2018 was the non-performing loans of the banks the highest. The study concluded that even though banks have all the risk management systems in place non-performing loans are still increasing.
\end{abstract}

\section{Subject Areas}

Economics

\section{Keywords}

Risk Management, Credit Risk, Home Equity Loans, Non-Performing Loans 


\section{Introduction}

Banks are not like the other industrial organizations or companies, banks create value using their liabilities and assets for the shareholders (Stulz, 2015) [1]. Banks are rapidly changing but the fundamental goal of banks remains the same and that is to maximize the return on the risks the bank takes (Kiyai, 2013) [2]. According to Kiyai (2003) [2], banks manage different types of risks. This brings us to the term risk management, Hubbard (2017) [3] "being smart about taking chances" (p. 28). Banks are in a business of risk. They face different types of risks e.g. market risk, credit risk, operation risk, technology risks, liquidity risk, insolvency risk, interest rate risk (Saunders, Cornnet 2009). Credit risk is the one risk that the paper will be focusing on, however banks provide different types of financing in the form of loans.

There are different types of loans, business loans, farming loans, mortgage loans, home equity loans and consumer loans. With each of these loans there are risks associated with them. The Royal Society (1983) view risk as to the probability that a particular adverse event occurs during a stated period of time, or results from a particular challenge. While (Hubbard, 2017) [3] defines it as "the probability and magnitude of a loss, disaster, or other undesirable events", he also gives a shorter equivalent definition which is very easy to understand he explains it as "something bad could happen". So, risk is the possibility that something bad could happen. Banks have to manage these possible adverse or undesirable events this is called risk management. Risk management is "the identification, assessment, and prioritization of risks followed by coordinated and economical application of resources to minimize, monitor, and control the probability and/or impact of unfortunate events" as stated by Hubbard D. W. (2009) [4] defines it as the systematic use of organization-wide processes of identity, assess, manage, and monitor risks such that aggregated information can be used to protect, release, and create value.

A similar study was done in Pakistan in the year 2012. It looked at different risk management procedures that could help banks in Pakistan avoid disastrous crises and see what risk management procedures are already in place in Pakistan. The study also aimed to identify the different strategies banks in Pakistan can use to have low non-performing loans. The study revealed that there was no proper tool for risk management to assist the banks in this objective. Study concluded that non-performing loans are increasing and are becoming a threat to the profitability of banks (Haneef, Riaz, Ramzan, Rana, Hafiz \& Karim, (2012) [5].

Loans are the main source of income for banks and are the main source to generate loss (Dicevska, Karadjova \& Jolevski, 2018) [6]. During the years of 2008 and 2009 many banks have faced the biggest challenge called the global financial crises. Even though many banks suffered severely, many say that banks in the Sub-Saharan Africa were not affected directly and severely as other banks. That does not mean that the banks did not suffer from the crises. Sub-Saharan 
African countries' banking systems were indirectly affected by the crisis through trade linkages and exchange rate depreciation, which pushed up the people borrowing's financial problems causing the increase of non-performing loans ( $\mathrm{Ni}$ kolaidou \& Vogiazas., 2017) [7]. The amount of loans taken out by Namibians that are not paid on time has massively increased from 1.3 billion to 2.3 billion in 2017 as stated in the bank of Namibia 2017 annual report (Immanuel\& Ngutjinazo, 2018) [8]. The non-performing loans are increasing and this can lead to the possibility of bank failures as well as the increasing of the unemployment rate in the Economy (Koju, Abbas \& Wang, 2018) [9].

The increase of non-performing loans can slow down the growth of the Namibian economy, this why banks have to maintain a low ratio of non-performing loans. The Banking sector has a pivotal role in the development of an economy. It is the key driver of economic growth of the country (Sharma, 2009) [10]. This why banks do risk management to avoid probable failure in the future but risk management is not a free-of-cost activity (Nasr \& Shafiq, 2010) [11]. It is as a result of this problem aforementioned that the study sought to investigate the risk management impact on non-performing loans and profitability in the $\mathrm{Na}$ mibian banking sector.

The paper is grounded on the following research objectives:

1) How does risk management affect non-performing loans and profitability in the Namibian Banking sector?

2) The implication of the impact of risk management on non-performing loans.

\section{Literature Review}

Analyzing how risk management protects the banks from the effects of nonperforming loans.

Crane, Gantz, Isaacs, Jose, and Sharp (2013) [12] stated that "risk is what makes it possible to make a profit. If there was no risk, there would be no return to the ability to successfully manage it" (p. 1). This is the reason why banks must take risks but they have to be considered of the types of risk they take because banks are a fragile institution and they are built on customer trust and brand reputation, "Risks and Risk Management in the Banking Sector". Risk management is there to help banks avoid any negative consequences that could harm the bank or its assets and liabilities (Županović, 2014) [13].

The global financial markets are constantly growing and changing, with these changes comes along a variety of risks (Bhatti \& Misman, 2010) [14]. One of the risks banks face is credit risk. According to Makri, Tsagkanos, and Bellas, (2014) [15] "one of the most common indicators that is used to identify credit risk is the ratio of non-performing loans" (p. 193). The analysts expect the number of non-performing loans to increase in the years coming (Makri, Tsagkanos, and Bellas, 2014) [15].

\subsection{The Effects of Non-Performing Loans on Banks}

According to Brownbridge (1998) (as cited by Sheefeni 2015) [16] "most empir- 
ical researcher's supports confirm that most banking failure or banking crisis has been caused by non-performing loans" (p. 1526). Non-Performing Loan (NPL) according to the (International Monetary Fund, 2011), is any loan in which: interest and principal payments are more than 90 days overdue or more than 90 days' worth of interest has been refinanced, capitalized, or delayed by agreement; or payments are less than 90 days overdue but are no longer anticipated.

Non-performing loans have direct impact on the banks and an indirect impact on the country at large. Bank failure causes crisis and has negative impact on the economy (Sheefeni, 2015) [16]. To understand how non-performing loans can cause a bank to fail, the study has to look at how non-performing loans impacts the bank. Loans are banks main source of income and an increase in non-performing loans definitely decreases interest income of banks (Sheefeni, 2015) [16]. Ghosh., (2017) [17] did a study in the USA to identify the impact non-performing loans have. The study found that the increase in non-performing loans shows credit supply constraints for banks and hinders a bank's ability to supply more loans. This means that banks with high non-performing loans will find it difficult to provide more loans for their customers and may end up losing customers. Ghosh, (2017) [17] stated that "both construction sector employment and GDP growth are affected the most with a rise in total (NPLs)" (p. 321). John (2018) [18] summarizes the effects of non-performing loans in four points: 1) there are high chances that the bank's ability to liquidate can be affected. 2) The bank's turnover is slowed down as there are no payments made and this is preventing the bank to make give new loans. 3) The banks revenue is reduced by the battel of interest and commission on turnover. 4) The bank is unable to serve all customers efficiently as there are limited funds. According to Kirui (2014) [19] "when amounts of disposal non-performing loans exceed their profits it will reduce banks' net worth and lower their risk-taking capacity, making it difficult to invest funds in risky projects and to realize potentially productive businesses" (p. 3).

The study done in Kenya found that non-performing has a negative effect on the profitability of banks. The study also found that bank may start to look at more risk-free investments to reduce risks. Non-performing loans also affect the operational efficiency of banks (Kirui, 2014) [19]. Another study done on Kenyan commercial banks however this study focused on the KCB Group Limited. The study also found that non-performing loans impairs a bank's ability to lend loans because of the diminished core capital. The increase in provision for bad loans decreases the banks' profits and high levels of non-performing loans can lead to undercapitalization of the bank and can cause job losses (Nyasaka, 2017) [20].

There are quite a number of factors that causes non-performing loans, many literatures call them determinants of non-performing loans. "The academic literature provides evidence to suggest a strong connection between the (NPL) and many macroeconomic variables. Among factors cited by the literature as significant determinants, there are: the real interest rate, the annual GDP growth, the 
annual inflation rate, loans growth, the real exchange rate, the unemployment rate, money supply (M2) etc." (Messai, \& Jouini, 2013, p. 853) [21]. One study was done on 85 large banks from three countries (Italy, Greece \& Spain). The study found a negative relationship between the growth rate of GDP and nonperforming loans. The positive relationship between the unemployment rate and non-performing loans shows that unemployed customers cannot repay their loans (Messai and Jouini 2013) [21].

Vogiazes \& Nikolaidu (2011) did a study in Romania to determine the determinants of non-performing loans. The results showed that construction and investment expenditure, unemployment, inflation rate and Romania's external debt to GDP as well as money supply broadly defined were the main determinants of non-performing loans in Romania (as cited in Akinlo \& Emmanuel, 2014) [22]. There was a study done in Nigeria that found the determinants of NPL have to be exchange rate, credit rate, and lending rate. These determinants tend to increase non-performing loans. The study also found that the stock market has a negative impact on NPLs (Akinlo \& Emmanuel, 2014) [22].

The study done in Ghana was to determine the causes of non-performing loans. The study found that larger banks were more exposed to macroeconomic factors (i.e., previous year's inflation, real gross domestic product (GDP) per capita growth and real effective exchange rate) while smaller banks are more exposed to bank-specific factors (i.e., previous year's NPL, bank size, net interest margin (NIM), and current year's loan growth) (Amuakwa-Mensah \& Boakye-Adjei, 2015) [23]. According to Sheefeni (2015) [16] based on a study done in Namibia, "return on assets, return on equity, loan to total asset ratio, log of total assets are the main determinants of non-performing loans" (p. 1539). This study mainly focused on the bank-specific factors. However according to Ugoani (2016) [24] "for most failed banks, the real problem is systemic the in nature and rooted in a bank's credit culture and management style" (p. 304).

\subsection{The Effects of Risk Management on Banks}

"Risk Management is the application of proactive strategy to plan, lead, organize, and control the wide variety of risks that are rushed into the fabric of an organizations daily and long-term functioning" (Kanchu \& Kumar, 2013, p. 145) [25]. The objective of risk management is to not to avoid taking risks but to make sure that risks are consciously taken with full knowledge to able to measure it and reduce it. According to Kanchu \& Kumar (2013) [25] the aim of risk management is to increase the value of profit and making sure the bank has a longer term in regards of solvency. Risk management allows banks to take risks wittingly and to predict any changes accordingly (Kanchu \& Kumar, 2013) [25]. Van Gestel \& Baesens, (2008) said "banks are exposed to credit, market, operational, interest rate and liquidity risk. Efficient management on these risks is necessary for banks to reduce its losses on earning, insolvent and those depositors cannot be refunded" (as cited in Li \& Zou, 2014) [26]. Risk management that is 
well implemented can give the bank a great advantage. According to Wenk (2005) these benefits are: better financial performance, better system for strategy setting, improved service delivery, competitive advantage, less time spent on dealing with problems and less unwanted surprises, increased likelihood of change initiative being achieved, closer internal focus on doing the right things properly, more efficient use of resources, reduced waste and fraud (as cited in Mwangi, 2013) [27]. Li (2007) [28] states "Without risk management, there would be no visibility on possible outcomes, and on the possible fluctuations of profitability, nor any way to control the uncertainty over expected earnings" (p. 61).

Li and Zou (2014) [26] did a study in Europe where they looked at 47 large banks. They used capital adequacy ratio (CAR) and Non-performing loan ratio (NPLR) as proxies for risk management and return on assets (ROA) and return on equity (ROE) as proxies for profitability. Their study found a negative relationship between ROA and NPLR as well as a negative relationship between ROE and CAR. This shows that the higher non-performing loan ratio the less capital there will be available for investments. Anga (2015) [29] did a study in South Africa and the study found that credit risk management can be used to increase the profitability of the banks. The study also concluded that controlled variables also affected profitability, these variables are banks size operating expenses and economic growth.

Risk management is an important aspect as mentioned earlier. Risk management can help the bank in different aspects but the main aspect is that risk management can help banks improve profits. The different studies used proxies as indicators of risk management allowing them to see the relationship between profitability and risk management. One of the proxies used for risk management is non-performing loan ratio. The study will be looking at how risk management protects the banks from the effects of non-performing loans.

\subsection{How Risk Management Protects Banks from the Effects of Non-Performing Loans}

Hanleef et al. stated that non-performing loans are increasing because of the lack of risk management and that can be threat to the bank's profitability (as cited by Makori, 2018) [30] The increase in non-performing loans causes the income and interest income of banks to decrease as loans are a bank's main source of income (Sheefeni 2015) [16]. Bekhet, \& Elleter (2014) [31] says "credit risk is the most critical and the biggest challenge facing banks' management” (p. 20). The banks introduced risk management to be able to control and minimize the impact of risks (Table 1). The risk management allows process banks to achieve its objectives.

According to Bekhet, \& Elleter (2014) [31] risk estimate helps banks make credit decisions and if the bank is not able to determine the risk precisely could adversely affect the credit management. They also stated that poor risk evaluation of credit risk could lead to huge money loss. Makori (2018) [30] did a study 
Table 1. Risk management process.

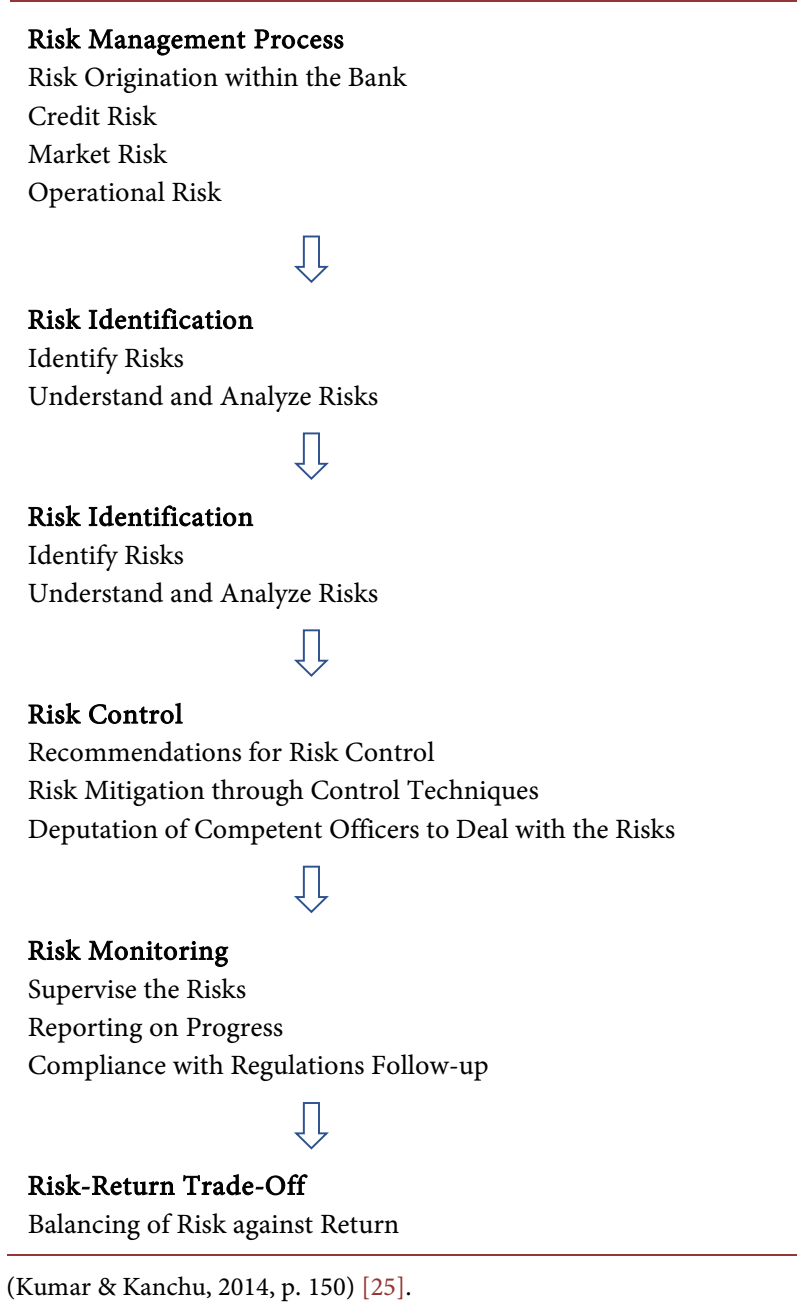

in Kenya and the study focused of credit risk management and the level of non-performing loans. The study found that the risk management process allowed banks to identify risks and control them. The study found that through risk monitoring the banks could follow up on borrowers and through risk monitoring the credit committee can give the management recommendations on where the loan performance is poor. The study agrees that by involving credit committees in making decision when it comes to loans helps reduce loan defaults.

According to Rose \& Hudgins (2012) [32] banks have to view three objectives before granting a loan. 1) The credit worthiness of the customer by looking the Cs of credit; character, cash, capacity, collateral, conditions and control. The Cs of credit helps banks to identify whether the customer can pay out the credit when due. 2) Is it possible to properly structure and document the agreement? 3) Can the lender complete its claim against assets or earnings of the customer? These objectives help banks identify bad loan applications and good loan applications. Rose \& Hudgins (2012) [32] also states that loan officers prefer to have 
more than one safety net (collateral) to protect the funds they placed at risk with the customer.

\subsection{Analyzing How Banks Anticipate Non-Performing Loans}

The need to identify early warning signs of non-performing loans has become an important activity for the managers and credit controllers (Ozili, 2015) [33]. According to Carling (1998) by ranking customers according to predicted default probabilities, a bank will have a chance to minimize the expected default or misclassification rate subject to some exogenous acceptance rule (as cited by Özdemir \& Boran, 2004) [34]. According to Berge and Boye (2007) [35] problem loans are divided into two categories, non-performing loans and non-delinquent loans. Non-delinquent loans are considered to be the types of loans banks consider to be doubtful (Berge and Boye, 2007) [35].

Bank's offer different types of loans to their customers, according to Nguyen (2016) [36] when a bank offers a new loan this loan can be placed into one of four categories: consumer loans, business loans, real estate loans and government-sponsored loans. Consumer loans are amortizing loans (loans which are paid over a period of time with equal installments), which services household needs under the assumption that the borrower is a natural entity (Ganopoulou, Giapoutzi, Kosmidou \& Moysiadis, 2015) [37]. There different types of consumer loan products banks offer which is divided into secured loans and unsecured loans. They are housing loans, student loans, personal loans, car loans, credit cards and pay day loans. Business loan is a debt of which the organization is obligated to pay back (Sheahan, n.d.) [38]. Real estate loans are also known as mortgage loans, it is commonly used to by homebuyers to finance real estate. The borrowers promise to pay back the loan plus interest over a specified period (Esajian, 2015) [38].

\subsection{Identifying Different Risk-Management Strategies That Can Help Banks Avoid Non-Performing Loans}

According to the Juneja P. (2001), he defines strategy as "an action that managers take to achieve one or more organization goals". He also states that strategy is about combining organizational activities and utilizing the scarce resources to meet the objectives of the organization. The development group said that risk management strategy provides a structured and consistent approach to identifying, assessing and managing risk. It allows the business to build a process of continuous updates and reviewing actions taken from the assessment (2011). Ntiamoah, Koranteng \& Brew (2014) [39] concluded in their study that risk management, firm policies and strategy formulation guarantees profitability.

\subsection{The Importance of Having an Effective Strategy}

In today's business environment, the banking industry is under enormous pressure from many different parties to remain financially sound and exercise good 
judgment when making decisions that can affect the general well-being of our economy (Fathi, Willson \& Maldonado, 2017). Developed countries have shown that banks cannot just depend on collateral as the values of assets are getting harder to predict and to realize through liquidation and the more uncertain the values of assets are the riskier lending is (Saunders \& Allen, 2010) [40].

\subsection{Identifying the Differences between Credit Risk Strategies and Credit Policies}

Mashanovich (2017) explains that credit risk strategy is a process that follows after scorecard development is done and before its implementation and it tells us how to interpret the customer score. It determines what appropriate actionable treatment should be taken based on the score of the customer. According to the Basell Committee (2004) [41], each and every bank should develop a credit risk strategy that establishes the objectives guiding the bank's credit-granting activities and adopt policies and procedures on how to conduct these procedures. The credit risk strategy must include:

- The statement of the bank's willingness to grant credit based on the exposure type.

- The target market and characteristics the bank wants to achieve in its credit portfolio.

- It should provide a continuity approach and be viable in the long run.

(Basell Committee, 2004) [41]

Ntiamoah, Koranteng \& Brew (2014) [39] explains that credit policies form the framework for granting and lending activities of the bank. Policies and procedures enable's banks to have a proper credit granting standards, to be able to monitor and control credit risk. The credit policy includes detailed procedures and guidelines for the size of a loan portfolio, the maturity periods of the loan, security against loan, the credit worthiness of the borrower, the liquidation of loans, the limits of lending authority Ntiamoah, Koranteng \& Brew (2014) [39]. Credit policies are necessary to show how organizations do their business and assists in avoiding potential confusions and misunderstandings Ntiamoah, Koranteng \& Brew (2014) [39]. Credit policies also stipulate how and when reporting should be done and the reporting illustrates the effectiveness of the credit policy Ntiamoah, Koranteng \& Brew (2014) [39].

\subsection{Risk Management Strategies for Reducing Non-Performing Loans}

Risk management strategies are decided by top level management because the importance of making risk management part of the high level strategies is because of the lessons taken by industry actors from the 2007 financial crisis (Mikes, 2009) [42]. A study in done Montenegro looked at the overall mapping of the recovery of past due loans. The study looked at an approach introduced in the country called the Podgorica Approach. The aim of the approach is to achieve greater stability in the banking industry. The approach would allow 
banks to collect a significant portion of their debt. The state would be able to get more stable companies to settle their obligations. The approach's assumption is to allow companies to first settle their consolidation to help boost their revenues (Stijepović, 2014) [43].

Mazzù \& Muriana (2018) [44] did a study to help organization choose the best approach on how to reduce non-performing loans through on balance sheet or off balance sheet method. The on-balance sheet approaches follow a gradual recovery of non-performing loans over a long period of time. This is done through liquidation/foreclosure activities. The on-balance sheet approach is divided into two distinctive styles: passive and dynamic. The passive style has no clear definition of recovery targets and the process is run by legal officers. The activities involve executing standard procedures and the style is mostly suited for well secured assets and in economic upswings. Dynamic style has the aim of optimizing the returns of the bank. It sets explicit recovering targets for the bank. The off balance sheet approaches consists of cutting out and removing non-performing loans from the bank's balance sheet by transferring them to external audits.

The most favorable strategy to reduce non-performing loans according to Richard (2011) [45] is to establish a good relationship with the borrowers. This was achieved through assisting, advising borrowers on how solve their problems and deliver great services. This study was done in Tanzania.

\section{Methodology}

The proposed study has adopted the qualitative research methodology to analyse the impact of non-performing loans on the profitability on banks. The researcher also adopted the archival research strategy as the study made use of financial reports of the banks as the main source of data. An interpretivism research philosophies was adopted since secondary data research is also popular with interpretivism philosophy (Dudovskiy, 2013) [46].

\subsection{Sampling}

Sampling involves the selection of a number of study units from a define study population (Phrasisombath, 2009) [47]. Sampling is the process used to select the portion of the study that will be used in for the research project out of the population (Maree, et al., 2012) [48]. The total population consisted of six banks found in Namibia.

The researcher has chosen the purposive sampling method for the study and selected four commercial banks operation in Namibia because the give loans to the public while the other two banks are the central bank and Namibia Post Bank which don't give mortgage and vehicle loans to the public and therefore do not qualify for this study. The researcher used secondary data from which was carefully selected from online newspaper articles and financial reports of the different banks to answer the research questions.

The researcher used the financial reports of the following banks: First Nation- 
al Bank Namibia, Bank Windhoek Namibia, Nedbank Namibia and Standard Bank Namibia. This allowed the researcher to view the entire bank's performance and not just a certain branch.

\subsection{Data Analysis}

Marshal and Rossman (1999) described data analysis as the process of unscrambling of mass data which allows the researcher to bring order and structure to the data collected, it is creative and fascinating (as cited by Vosloo, 2014) [49]. Richmond (2006) [50] states that data analyses consist of the approaches of working with data collected to present the researcher's work. The data collected was qualitative. The researcher used graphs and charts to represent the data collected. The researcher used Excel as the Software to help develop the conclusion of the research. The data collected was used to analyze the impact of non-performing loans on the profitability of banks.

\section{Findings}

The non-performing loan data and profitability is presented in the succeeding graphs. This is then followed by a brief discussing.

\subsection{First National Bank of Namibia (FNB)}

According to the data collected during the year 2015 the non-performing loans had increased compared to the 2014. The researcher identified that Profit of the bank also had increase from the year 2014 to 2015. As shown in Figure 1 and Figure 2, the non-performing loans had a gradual increase through all 5 years, where it is the highest in the year 2018. The profit of FNB started with an increase from year 2014 till year 2016, after year 2016 the profit of the bank had a decrease for the last two years under observation [51] [52] [53] [54] [55].

\subsection{Bank Windhoek Namibia}

Bank Windhoek had an increase in the non-performing loans from the year 2014 to the year 2018. In the year 2018 there is major increase in the non-performing

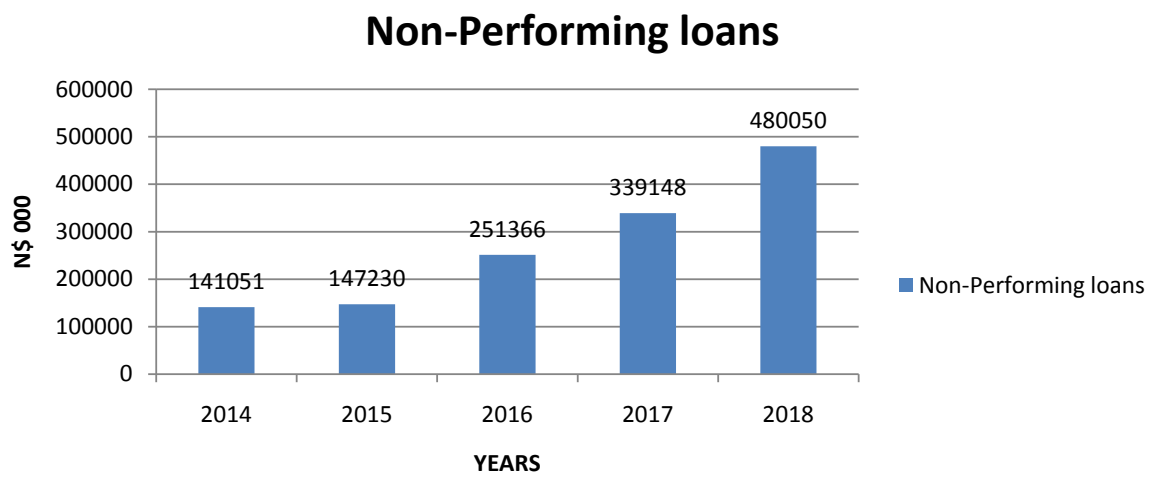

Figure 1. First national bank of Namibia (FNB) non-performing loans. Source: (FNB Annual Report, 2018) [55]. 
loans for that year, from $\mathrm{N} \$ 412,616$ to $\mathrm{N} \$ 829,390$ and 2018 being the highest of all the years under observation (Figure 3 ). The profit for the bank has a steady increase in during the 5 years (Figure 4) [56] [57] [58] [59] [60].

\subsection{Nedbank Namibia}

Nedbank Nambia Annual reports shows that the profit of the bank gradually increased through the first 4 years and in the last year the bank's profit shows an enormous increase compared to the previous years. As shown in Figure 5, the Non-Performing loans of the bank also showed an increase in each year, but during the year 2018 the non-performing loans had an astonishing increase compared to the previous year. Figure 6 shows the Nedbank Profit [61] [62] [63] [64] [65].

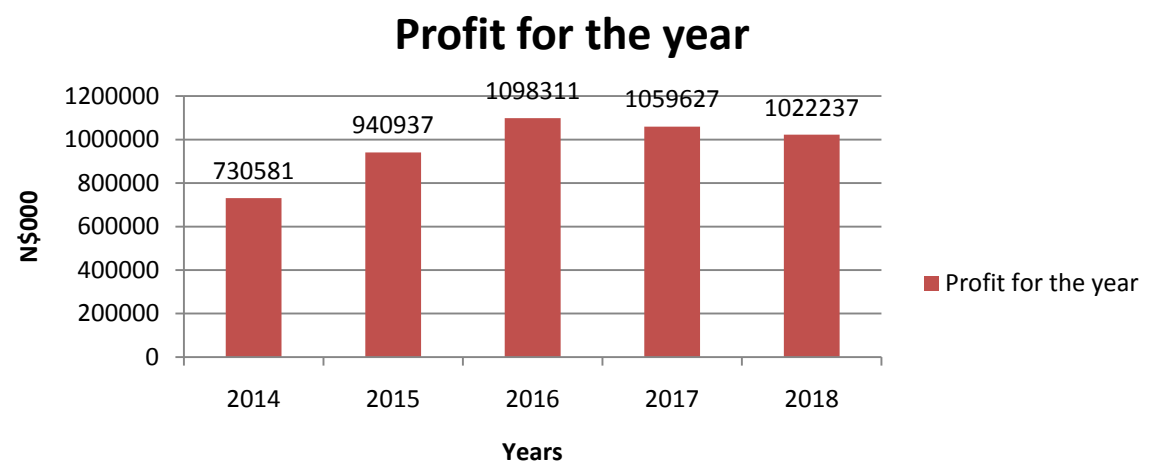

Figure 2. First national bank of Namibia (FNB) profit. Source: (FNB Annual Report, 2018) [55].

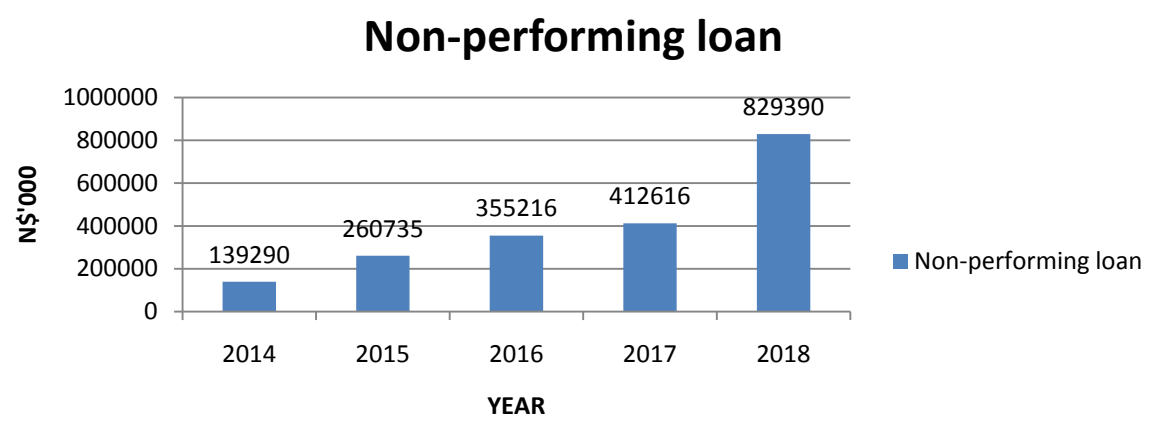

Figure 3. Bank Windhoek non-performing loans. Source: (Bank Windhoek Annual Report, 2018) [60].

\section{Profit for the year}

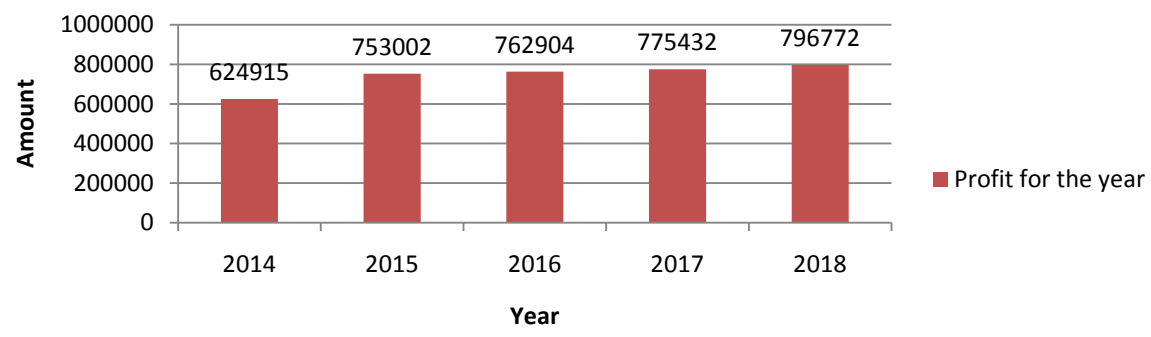

Figure 4. Bank Windhoek profit. Source: (Bank Windhoek Annual Report, 2018) [60]. 


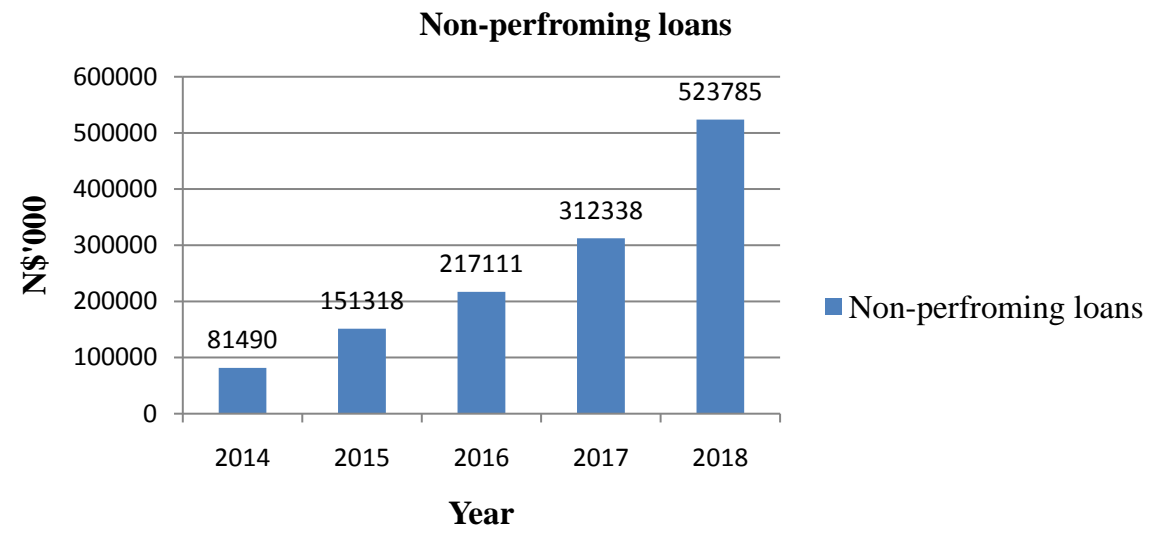

Figure 5. Nedbank non-performing loans. Source: (Nedbank Annual Report, 2018) [65].

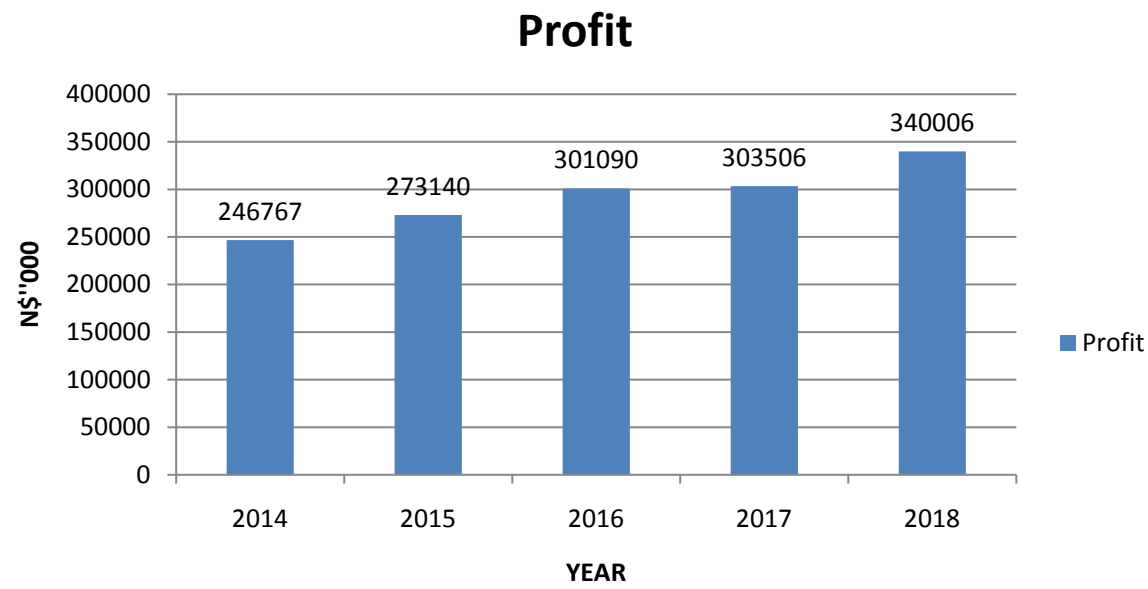

Figure 6. Nedbank profit. Source: (Nedbank Namibia Annual Report, 2018) [65].

\subsection{Standard Bank Namibia}

The Profit of standard Bank Namibia started off with a biggest increase of the four years in observation. In the year 2015 the profit increased from $\mathrm{N} \$ 362,090$ million to $\mathrm{N} \$ 52,431$ million. Since the year 2015 the bank did not see big changes in the profit growth but it continued to increase. The non-performing loans of the bank had a fluctuated over the 5 years, in the year 2014-2015 the non-performing loans increased, during the year 2015-2016 the non-performing loans decreased in value. The bank experienced another increase in the nonperforming loans from the year 2016 to 2017. Figure 7 and Figure 8 show the non-performing loans and profit of Standard Bank [66] [67] [68] [69] [70].

\subsection{Discussion of Findings}

\subsubsection{The Effect of Risk Management on Non-Performing Loans and Profitability in the Namibian Banking Sector}

The study looked at the different risk management reports of each bank in the 2018 annual reports. The research looked at who deals with the risk management and how credit risk in particular non-performing loans are dealt with.

Bank Windhoek Namibia's board of directors ensures that all practices and 


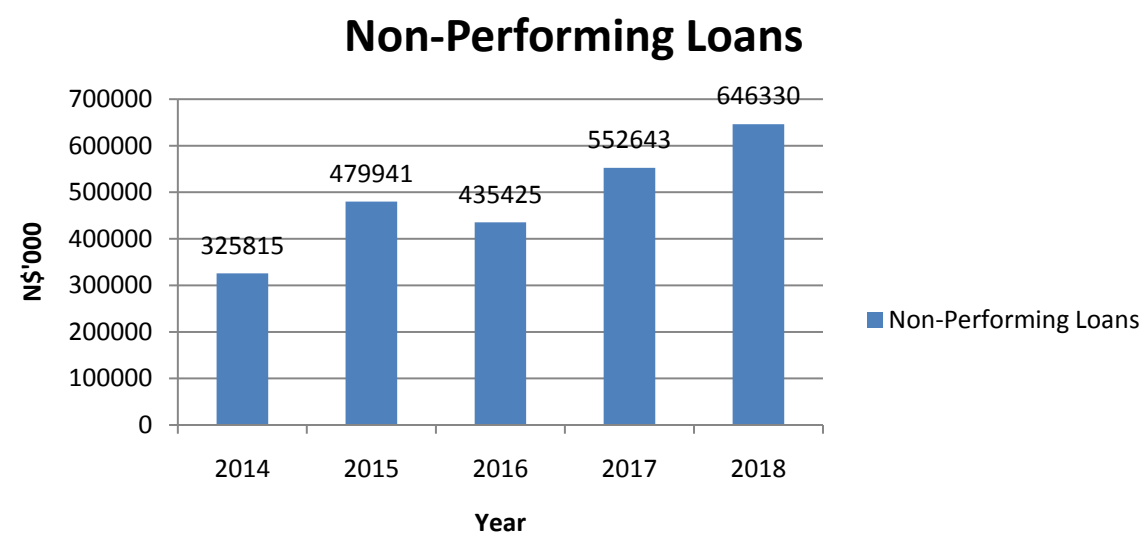

Figure 7. Standard bank non-performing loans. Source: (Standard Bank Namibia Annual Report, 2018) [70].

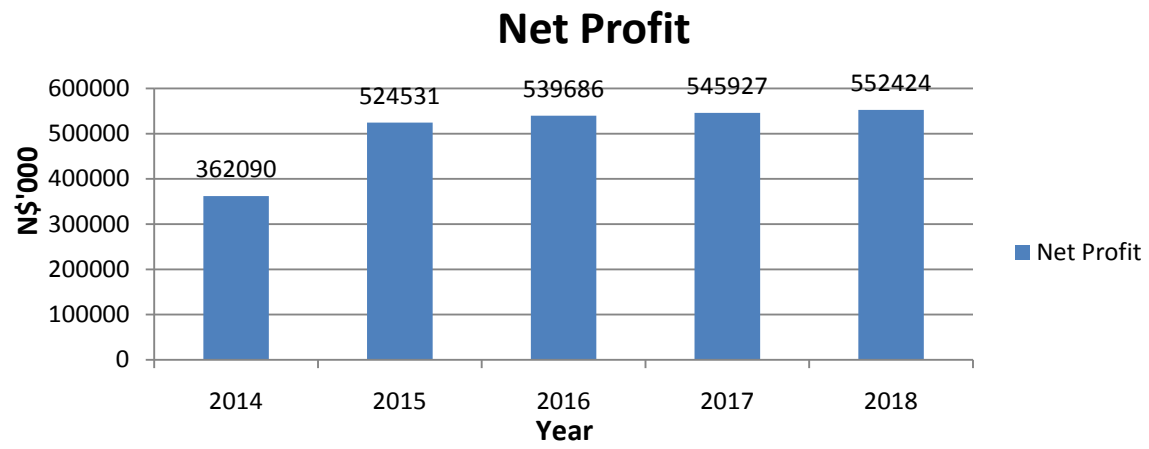

Figure 8. Standard bank profit. Source: (Standard Bank Namibia Annual Reports, 2018) $[70]$.

procedures are in place to protect the reputation of the bank. One of their responsibilities is to oversee the system of risk management. The board executive committee is to guide and execute the risk management strategies approved by the board of directors. Board risk committee is responsible for risk management among other responsibilities. Managements approach to risk management is to make sure that all risks are identified and ensures that the risks that are taken measures up to the returns. The bank has implemented systems and day to day activities to detect and prevent risks. The bank has a board credit committee and board lending committee which ensures that credit exposure remains in acceptable standards. Exposure to credit risk is managed upfront when an application for apply for credit. The credit facility regulates the borrower's ability to repay the loan on a daily basis (Bank Windhoek Annual Report 2018) [60].

Nedbank's credit department assesses all the exposures the bank faces regarding credit risk. The bank has a proactive risk management and involves the clients through regular area management initiatives and these are clients with distressed assets. Report of the Group Risk and Capital Management Committee oversees the credit of the bank and are responsible for the credit impairment and going monitoring of the overall credit portfolio. The Bank currently applies the standardized approach for credit risk and this is for regulatory purposes under 
Basel II (Nedbank Namibia Annual Report 2018) [65].

First National Bank of Namibia focus on assessing, managing and monitoring all known forms of risk the bank is faced with. The risk management framework assesses the impact of the cycle on the group's portfolio; understands and price appropriately for risk; and originates within cycle appropriate risk appetite and volatility parameters. The senior credit risk committee has the responsibility for managing the credit risk. The bank places appropriate limits and ensures accuracy of the credit risk reports. The bank has comprehensive policies and controls allowing them to have a strong credit risk management and has developed internal quantitative models to help assess probability of default, exposure at default and loss given default (First National Bank Annual report 2018) [55].

Standard Bank of Namibia's board uses reports from different committees within governance structure to evaluate the risk management of the organization. The risk management framework consists of risk governance committees at a board and management level management organization structure to support the three lines of defense model, risk governance standards and policies to support the risk governance standards. Board subcommittees that is responsible for effective risk management is made of the board audit committee, the board risk committee, board IT committee and board credit committee. The bank has a three line defense. Each defense line has a different responsibility. The first line measures and controls day to day risk according to governance framework. The second line of defense provides and independence oversight of the first line of defense and reports to different board governance committees and the last line of defense also provides an independent oversight over the second line of defense. The bank uses historical data to estimate future cash flow for credit applications with similar credit risk characteristics. The bank regularly monitors the timing and future cash flows to reduce the amount of estimate losses and actual loss (Standard Bank Namibia Annual Report 2018) [70].

\subsubsection{The Implication of the Impact of Risk Management on Non-Performing Loans}

For the four banks that were included in the study the articles found, found that for the year 2014 the non-performing loans were the lowest in all four banks. The non-performing loans than increased consecutively for three of the banks but for one bank (Standard Bank Namibia) experienced a decrease in the year 2016 but it increased again in the year 2017. The year 2018 showed a major increase of non-performing loans across all four banks. This showed to be the year all four banks struggled with the non-performing loans.

Study found that the profit of the banks were also the lowest during the year of 2014 for all four banks which is a good thing as you don't want your previous year's profit to be higher than the current year. Three out of four banks showed a positive increase in profit across all five years. Except for the one bank which had shown an increase in the profit till the year 2016 and experienced a decrease in profit from the year 2017 until 2018. 
The graphs showed that both profit and non-performing loans increased from the year 2014 till 2018. During the worst period of all five years where the non-performing loans were the highest the profit of the banks still increased. This shows that non-performing loans does not have such a massive impact on the profit of the banks. It still does however have an impact as the profit could've been more because of outstanding interest on loans that are 90 days past due.

The banks has shown that risk management is an important activity as it is not left up to the lower level management to see if it is implemented. It is the responsibility of the board of directors to ensure that there are procedures in place to ensure a good credit standard. This protects the image of the different banks and shows that banks are protecting the investments they get. Although the banks have all these systems in place to help reduce non-performing loans the non-performing loans are still increasing.

\section{Conclusions and Recommendations}

\subsection{Conclusions}

The aim of the study was to determine the impact non-performing loans have on the profit of commercial banks in Namibia. The study also looked at the impact of risk management on non-performing loans. The study found that even though the banks have risk management systems in place external factors still play a major role in the increase of non-performing loans.

The study also focused on the implication of the impact of risk management on non-performing loans. The banks have shown that risk management is an important activity as it is not left up to the lower level management to see if it is implemented. It is the responsibility of the board of directors to ensure that there are procedures in place to ensure a good credit standing.

\subsection{Recommendation for Future Research}

The study was limited to two the impact of two aspects of non-performing loans which were risk management and profitability. However, future researchers can look into interest rate fluctuations of the banks. The study also would recommend future researchers to look into how information technology is playing a role in assisting banks when it comes to risk management.

\section{Conflicts of Interest}

The authors declare no conflicts of interest regarding the publication of this paper.

\section{References}

[1] Stulz, R.M. (2015) Risk-Taking and Risk Management by Banks. Journal of Applied Corporate Finance, 27, 8-18. https://doi.org/10.1111/jacf.12099

[2] Kiyai, T.K. (2003) Bad Debts Restructuring Techniques and Non-Performing Loans of Commercial Banks in Kenya. Doctoral Dissertation, University of Nairobi, Nairobi. 
[3] Hubbard, D.W. (2017) The Failure of Management: Why It's Broken and How to Fix It. John Wiley \& Sons, Inc., Hoboken.

[4] Hubbard, D.W. (2009) The Failure of Management: Why It's Broken and How to Fix It. John Wiley \& Sons, Inc., Hoboken.

[5] Haneef, S., Riaz, T., Ramzan, M., Rana, M.A., Hafiz, M.I. and Karim, Y. (2012) Impact of Risk Management on Non-Performing Loans and Profitability of Banking Sector of Pakistan. International Journal of Business and Social Science, 3, 307-315.

[6] Dicevska, S., Karadjova, V. and Jolevski, L. (2018) The Impact of Non-Performing Loans on Households on the Financial Performance of Banks in Macedonia 1. International Scientific Conference on Service Sector 2018, Ohrid, 14-15 September 2018, 147-160.

[7] Nikolaidou, E. and Vogiazas, S. (2017) Credit Risk Determinants in Sub-Saharan Banking Systems: Evidence from Five Countries and Lessons Learnt from Central East and South East European Countries. Review of Development Finance, 7, 52-63. https://doi.org/10.1016/j.rdf.2017.01.003

[8] Immanuel, S. and Ngutjinazo, O. (2018) More Namibians Fall into Debt Hole. Namibian, Namibia press agency, Windhoek.

[9] Koju, L., Abbas, G. and Wang, S. (2018) Do Macroeconomic Determinants of Non-Performing Loans Vary with the Income Levels of Countries? Journal of Systems Science and Information, 6, 512-531. https://doi.org/10.21078/JSSI-2018-512-20

[10] Sharma, D. (2009) India's Leapfrogging Steps from Bricks-and-Mortar to Virtual Banking: Prospects and Perils. IUP Journal of Management Research, 8, 45-61.

[11] Shafiq, A. and Nasr, M. (2010) Risk Management Practices Followed by the Commercial Banks in Pakistan. International Review of Business Research Papers, 6, 308-325.

[12] Crane, L., Gantz, G. and Isaacs, S.I. (2013) Introduction to Risk Management. Journal of Business Strategy, 3, 41-43.

[13] Županović, I. (2014) Sustainable Risk Management in the Banking Sector. Journal of Central Banking Theory and Practice, 3, 81-100.

https://doi.org/10.2478/jcbtp-2014-0006

[14] Bhatti, I. and Misman, F.N. (2010) Risks Exposure in Islamic Banks: A Case Study of Bank Islam Malaysia Berhad (BIMB). Australian Centre for Financial Studies-Finsia Banking and Finance Conference 2020, Windhoek, February 2020, 6. https://doi.org/10.2139/ssrn.1632849

[15] Makri, V., Tsagkanos, A. and Bellas, A. (2014) Determinants of Non-Performing Loans: The Case of Eurozone. Panoeconomicus, 61, 193-206. https://doi.org/10.2298/PAN1402193M

[16] Sheefeni, J.P.S. (2015) Evaluating the Impact of Bank Specific Determinants of Non-Performing Loans in Namibia. Journal of Emerging Issues in Economics, Finance, and Banking, 4, 1525-1541.

[17] Ghosh, A. (2017) Impact of Non-Performing Loans on US Product and Labor Markets. Journal of Financial Economic Policy, 9, 302-323. https://doi.org/10.1108/JFEP-01-2017-0003

[18] John, N.N. (2018) Nonperforming Loans Portfolio and Its Effect on Bank Profitability in Nigeria. Independent Journal of Management \& Production, 7, 303-319.

[19] Kirui, S. (2014) The Effect of Non-Performing Loans on Profitability of Commercial Banks in Kenya. Research Submitted for Master Degree Programme, University of 
Nairobi, Nairobi.

[20] Nyasaka, F.O. (2017) The Relationship between Credit Risk Management Practices and Non-Performing Loans in Kenyan Commercial Banks: A Case Study of KCB Group Limited. Doctoral Dissertation, United States International University-Africa, Nairobi.

[21] Messai, A.S. and Jouini, F. (2013) Micro and Macro Determinants of Non-Performing Loans. International Journal of Economics and Financial Issues, 3, 852-860.

[22] Akinlo, O. and Emmanuel, M. (2014) Determinants of Non-Performing Loans in Nigeria. Accounting \& Taxation, 6, 21-28.

[23] Amuakwa-Mensah, F. and Boakye-Adjei, A. (2015) Determinants of Non-Performing Loans in Ghana Banking Industry. International Journal of Computational Economics and Econometrics, 5, 35-54. https://doi.org/10.1504/IJCEE.2015.066207

[24] Ugoani, J. (2016) Nonperforming Loans Portfolio and Its Effect on Bank Profitability in Nigeria. Independent Journal of Management \& Production, 7, 303-319. https://doi.org/10.14807/ijmp.v7i2.406

[25] Kumar, M.M. and Kanchu, T. (2013) Risk Management in Banking Sector-An Empirical Study. International Journal of Marketing, Financial Services \& Management Research, 2, 145-153.

[26] Zou, Y. and Li, F. (2014) The Impact of Credit Risk Management on Profitability of Commercial Banks: A Study of Europe. Macmillan, London.

[27] Mwangi, A.K. (2013) Effect of Financial Innovation on the Financial Performance of Deposit Taking Microfinance Institutions in Kenya. Unpublished MBA Project, University of Nairobi, Nairobi.

[28] Li, Y. (2007) Determinants of Banks' Profitability and Its Implication on Risk Management Practices: Panel Evidence from the UK in the Period 1999-2006. University of Nottingham Publishers, Nottingham.

[29] Anga, F.N. (2015) The Effect of Credit Risk Management on the Profitability of the Four Major South African Banks. University of Johannesburg, Johannesburg Press.

[30] Makori, N.W. (2018) Credit Risk Management and Level of Non-Performing Loans in Commercial Banks in Kenya. Accounting and Finance, 2, 1306-1323.

https://doi.org/10.31142/ijtsrd14296

[31] Bekhet, H.A. and Eletter, S.F.K. (2014) Credit Risk Assessment Model for Jordanian Commercial Banks: Neural Scoring Approach. Review of Development Finance, 4, 20-28. https://doi.org/10.1016/j.rdf.2014.03.002

[32] Rose, P.S. and Hudgins, S.C. (2012) Bank Management \& Financial Services. McGraw Hill, New York.

[33] Ozili, P.K. (2015) How Bank Managers Anticipate Non-Performing Loans. Evidence from Europe, US, Asia and Africa. Applied Finance and Accounting, 1, 73-80. https://doi.org/10.11114/afa.v1i2.880

[34] Özdemir, Ö. and Boran, L. (2004) An Empirical Investigation on Consumer Credit Default Risk (No. 2004/20). Discussion Paper, Turkish Economic Association, Ankara.

[35] Berge, T.O. and Boye, K.G. (2007) An Analysis of Banks' Problem Loans. Economic Bulletin, 78, 65-76.

[36] Nguyen, L. (2017) Credit Risk Control for Loan Products in Commercial Banks. Case: Bank for Investment and Development of Vietnam. Haaga-Helia University of Applied Sciences, Pajuniityntie.

[37] Ganopoulou, M. and Giapoutzi, F. (2015) Credit Scoring and Bank Lending Policy 
in Consumer Loans. International Hellenic University,Thermi.

[38] Sheahan, K. (n.d.) Definition of Business Loans. Small Business, 8, 55-58. https://www.fortunebuilders.com/real-estate-loan/

[39] Ntiamoah, E., Koranteng, E. and Brew, Y. (2014) Credit Risk Management: An Insight into Its Policies and Strategy Formulation. International Journal of Management Sciences and Business Research, 3, 55-58.

[40] Saunders, A. and Allen, L. (2010) Credit Risk Management in and out of the Financial Crisis: New Approaches to Value at Risk and Other Paradigms. John Wiley \& Sons, Inc., Hoboken. https://doi.org/10.1002/9781118267981

[41] Basell Committee (2004) Basel Committee on Banking Supervision, Bank for International Settlements. BIS Economic Papers, No. 46, 12-19.

[42] Mikes, A. (2009) Risk Management and Calculative Cultures. Management Accounting Research, 20, 18-40. https://doi.org/10.1016/j.mar.2008.10.005

[43] Stijepović, R. (2014) Recovery and Reduction of Non-Performing Loans-Podgorica Approach. Journal of Central Banking Theory and Practice, 3, 101-118. https://doi.org/10.2478/jcbtp-2014-0017

[44] Mazzù, S. and Muriana, F. (2018) A Strategic Approach to Non-Performing Loans Treatment in Banking: Options and Rules for Decision-Making. International Research Journal of Finance and Economics, 3, 51-53.

[45] Richard, E. (2011) Factors That Cause Nonperforming Loans in Commercial Banks in Tanzia and Strategies to Resolve Them. Journal of Management Policy and Practice, $12,50-58$.

[46] Dudovskiy, J. (2013) Consumer Decision Making Process: A Detailed Analysis. Business Research Methodology.

[47] Phrasisombath, K. (2009) Sample size and sampling methods. Faculty of Postgraduate Studies and Research University of Health Sciences, Vientiane.

[48] Maree, K., Creswell, J.W., Ebersöhn, L., Eloff, I., Ferreira, R., Ivankova, N., Jansen, J.D., Nieuwenhuis, J., Pietersen, J. Plano Clark, V.L. and van der Westhuizen, C. (2012) First Steps in Research. Revised Edition, Van Schaik Publishers, Hatfield.

[49] Vosloo, J.J. (2014) A Sport Management Programme for Educator Training in Accordance with the Diverse Needs of South African Schools. Doctoral Dissertation, North-West University Press, Potchefstroom.

[50] Richmond, B. (2006) Introduction to Data Analysis Handbook. Academy for Educational Development, Durham.

[51] First National Bank of Namibia (2014) Annual Report 2014. Macmillan Publishers, Windhoek.

[52] First National Bank of Namibia (2015) Annual Report 2015. Macmillan Publishers, Windhoek.

[53] First National Bank of Namibia (2016) Annual Report 2016. Macmillan Publishers, Windhoek.

[54] First National Bank of Namibia (2017) Annual Report 2017. Macmillan Publishers, Windhoek.

[55] First National Bank of Namibia (2018) Annual Report 2018. Macmillan Publishers, Windhoek.

[56] Bank Windhoek (2014) Annual Report 2014. Capricorn Investment Holding, Macmillan Publishers, Windhoek. 
[57] Bank Windhoek (2015) Annual Report 2015. Capricorn Investment Holding, Macmillan Publishers, Windhoek.

[58] Bank Windhoek (2016) Annual Report 2016. Capricorn Investment Holding, Macmillan Publishers, Windhoek.

[59] Bank Windhoek (2017) Annual Report 2017. Capricorn Investment Holding, Macmillan Publishers, Windhoek.

[60] Bank Windhoek (2018) Annual Report 2018. Capricorn Investment Holding, Macmillan Publishers, Windhoek.

[61] Nedbank Namibia (2014) Annual Report 2014. Macmillan Publishers, Windhoek.

[62] Nedbank Namibia (2015) Annual Report 2015. Macmillan Publishers, Windhoek.

[63] Nedbank Namibia (2016) Annual Report 2016. Macmillan Publishers, Windhoek.

[64] Nedbank Namibia (2017) Annual Report 2017. Macmillan Publishers, Windhoek.

[65] Nedbank Namibia (2018) Annual Report 2018. Macmillan Publishers, Windhoek.

[66] Standard Bank Namibia (2014) Annual Report 2014. Macmillan Publishers, Windhoek.

[67] Standard Bank Namibia (2015) Annual Report 2015. Macmillan Publishers, Windhoek.

[68] Standard Bank Namibia (2016) Annual Report 2016. Macmillan Publishers, Windhoek.

[69] Standard Bank Namibia (2017) Annual Report 2017. Macmillan Publishers, Windhoek.

[70] Standard Bank Namibia (2018) Annual Report 2018. Macmillan Publishers, Windhoek. 